\title{
Development of an Accounting Skills Simulation Practice System Based on the B/S Architecture
}

\author{
https://doi.org/10.3991/ijet.v13i10.9459 \\ Jianmei Liu ${ }^{(\varpi)}$, Rong Fu \\ Chongqing Three Gorges University, Chongqing 404100, China \\ 416071920 @qq. Com
}

\begin{abstract}
Nowadays, companies are more in need of accounting professionals with both theoretical knowledge and practical abilities. However, the traditional accounting teaching model in colleges and universities cannot train students in both aspects. In order to improve the practical abilities of accounting major students in colleges and universities and promote the accounting teaching upgrade and reform, this paper proposes an accounting skills simulation practice system based on the $\mathrm{B} / \mathrm{S}$ architecture, aiming at improving the comprehensive abilities of accounting students and teaching efficiency. The technical roadmap of this system adopts the $\mathrm{B} / \mathrm{S}$ as the network architecture of the teaching system, HTML and Java Script language as the system programming language and MySQL database as the data storage and management database. The system consists of user administration, knowledge base management, teaching content management, practical test score management and other modules, which not only achieves the self-evaluation on the full set of accounting skills, but also improves the accounting teaching efficiency and helps teachers gain more control over the teaching process. This study can serve as some guidance to colleges and universities in cultivating innovative and practical accounting talents.
\end{abstract}

Keywords-B/S; Java Script; MySQL database; accounting skills; simulation practice system

\section{Introduction}

The accounting profession is no longer limited to accounting positions in the narrow sense, but involves a wide range of jobs from corporate budgeting, warehouse management, market research analysis and bills to commodity retail, finance, trade and taxation [1]. There is a growing demand in the society for accounting talents who have both theoretical accounting knowledge and practical accounting skills. In this situation, the teaching model used in the accounting major in colleges and universities can no longer make students meet the social needs. In order to promote the reform of accounting education, computer and computer network technology have been gradually applied in the accounting teaching in universities and colleges, aiming to improve the teaching efficiency and form an accounting skills practice simulation training model [2]. 
Foreign accounting software is mostly commercialized management-centered accounting systems applied in large companies, but the high costs limit their application in colleges and universities [3]. There are also various types of domestic accounting software, such as Kingdee and UFIDA. However, due to the shortage of teaching resources in college accounting majors and the inconsistency between general accounting software and the accounting teaching outline in universities and colleges, accounting software has not been applied in college teaching on a massive scale [4]. Therefore, accounting teachers and students in colleges and universities do not know much about the accounting skills simulation practice software and have not achieved very good results using such software. With the imbalance increasing between the social demand for accounting talents and the output of accounting students in universities and colleges, it becomes very important to develop an accounting skills simulation practice system based on computer technology for the accounting teaching in colleges and universities [5].

This paper proposes an accounting skills simulation practice system based on the $\mathrm{B} / \mathrm{S}$ architecture, aiming at improving the comprehensive abilities of accounting students and teaching efficiency. The technical roadmap of this system adopts the $\mathrm{B} / \mathrm{S}$ as the network architecture of the teaching system, HTML and Java Script language as the system programming language and MySQL database as the data storage and management database. This paper first introduces relevant computer technologies and puts forward the functional requirements for the software system according to the teaching needs in accounting skills simulation practice in colleges and universities; then, on this basis, it completes the overall functional design of the system, achieves the accounting skills simulation practice function of the system through software debugging and displays relevant functions of the teaching system via system interface. With the aid of computer network technology, this system achieves data sharing and simulation practice testing in accounting teaching, which improves the efficiency of accounting teaching in colleges and universities, and lays a foundation for the cultivation of high-quality accounting talents.

\section{Introduction of related computer technologies}

\section{$2.1 \quad B / S$ mode}

(1) Structure of the accounting skills simulation practice system

The $\mathrm{B} / \mathrm{S}$ structure (browser/server mode) is an effective improvement of the $\mathrm{C} / \mathrm{S}$ structure with the development of Internet technology. It is implemented on the user interface through a browser, and most of its logic of practice is implemented on the server side. This, on one hand, reduces the load on the client computer and, on the other hand, improves the efficiency of system maintenance and upgrade [6]. The data access sequence of the $\mathrm{B} / \mathrm{S}$ mode is from the presentation layer to the application layer and then to the data layer. Therefore, the system architecture of the $\mathrm{B} / \mathrm{S}$ mode is also divided into a presentation layer, an application layer, and a data layer, as shown in Figure 1. 


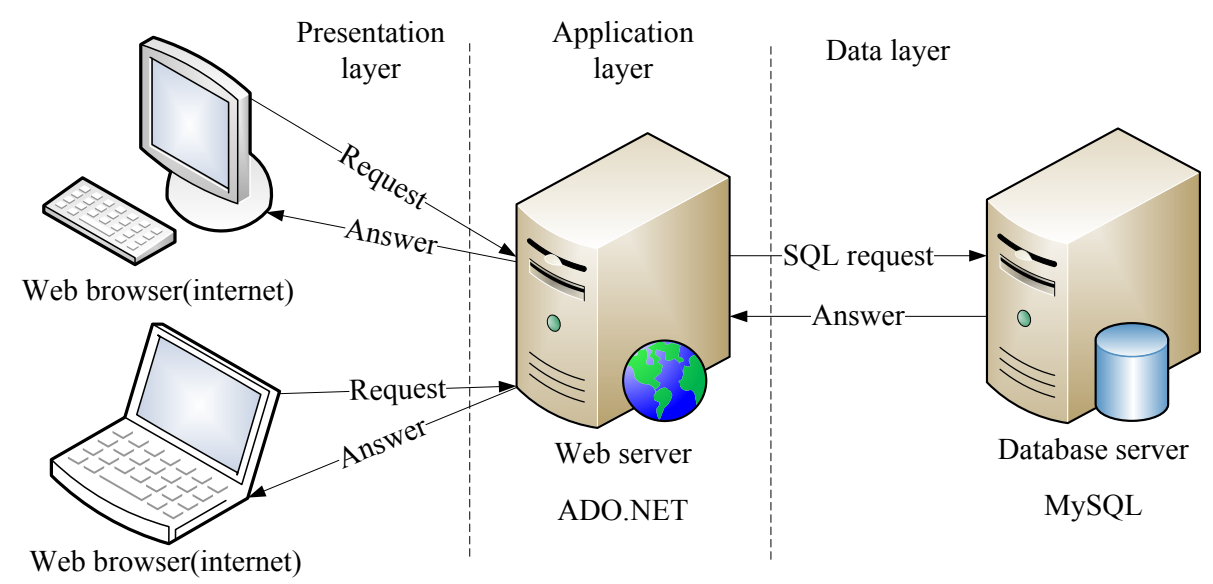

Fig. 1. B/S System architecture diagram

Built on the B/S architecture, the accounting skills simulation practice system is of a multi-layer architecture model. At the client, users can use network devices with the browser function such as computers and laptops to access data and use ADO.NET as the application server layer [7]. Java script is used as the programming language; and MySQL is used as the database management software.

(2) Functional advantages of the B/S architecture

The $\mathrm{B} / \mathrm{S}$ architecture software is easy to maintain and upgrade. The main maintenance work concentrates on the server side, which greatly improves the maintenance efficiency. The $\mathrm{B} / \mathrm{S}$ architecture is applicable to both the Linux operating system and the Window operating system and also all kinds of free databases, which reduces the system operating costs [8].

Compared with the $\mathrm{C} / \mathrm{S}$ mode, the $\mathrm{B} / \mathrm{S}$ mode can be built on a wide area network, so there is no need for a dedicated network hardware environment, giving this mode a stronger adaptability. Table 1 shows the differences between the $\mathrm{B} / \mathrm{S}$ mode and the $\mathrm{C} / \mathrm{S}$ mode in different aspects.

Through comparison in program architecture, hardware environment, software reuse, system maintenance, security requirements, processing and user interfaces, the $\mathrm{B} / \mathrm{S}$ mode is found more applicable to the current network development environment and more convenient and safer as well. So the accounting skills practice system developed based on the $\mathrm{B} / \mathrm{S}$ architecture can achieve information query, browsing and sharing by users on the browser side. 
Table 1. The difference between the $\mathrm{B} / \mathrm{S}$ and $\mathrm{C} / \mathrm{S}$ pattern

\begin{tabular}{|l|l|l|}
\hline \multicolumn{1}{|c|}{ Types } & \multicolumn{1}{|c|}{ B/S pattern } & \multicolumn{1}{c|}{ C/S pattern } \\
\hline $\begin{array}{l}\text { Program archi- } \\
\text { tecture }\end{array}$ & $\begin{array}{l}\text { B/S pattern based on multiple considera- } \\
\text { tions of security and access speed have } \\
\text { more high demand, support system for } \\
\text { building network components }\end{array}$ & $\begin{array}{l}\text { In C/S pattern, the program can pay more at- } \\
\text { tention to the process, and the authority can } \\
\text { be verified at multiple levels, but the speed } \\
\text { of the system is less consideration }\end{array}$ \\
\hline $\begin{array}{l}\text { Hardware envi- } \\
\text { ronment }\end{array}$ & $\begin{array}{l}\text { The B/S pattern is built on the WAN and } \\
\text { can be run with only the relevant operat- } \\
\text { ing system and browser }\end{array}$ & $\begin{array}{l}\text { The C/S pattern needs to be set up on a dedi- } \\
\text { cated network, and the LANs are connected } \\
\text { via a dedicated server and exchange data. }\end{array}$ \\
\hline Software reuse & $\begin{array}{l}\text { Multiple structures require relatively in- } \\
\text { dependent components to be reused }\end{array}$ & $\begin{array}{l}\text { Component reuse is not as good as B/S pat- } \\
\text { tern }\end{array}$ \\
\hline System maintain & $\begin{array}{l}\text { System maintenance costs are low and } \\
\text { can be upgraded seamlessly }\end{array}$ & $\begin{array}{l}\text { System upgrades are difficult and handling } \\
\text { problems is also more difficult }\end{array}$ \\
\hline $\begin{array}{l}\text { Safety require- } \\
\text { ment }\end{array}$ & $\begin{array}{l}\text { Faced with an unknown user base, its } \\
\text { ability to control security is relatively } \\
\text { weak }\end{array}$ & $\begin{array}{l}\text { Facing a relatively fixed user base, it has } \\
\text { strong control over security }\end{array}$ \\
\hline Solving issues & $\begin{array}{l}\text { Facing different user groups, geograph- } \\
\text { ical dispersion, and operating system } \\
\text { platform }\end{array}$ & $\begin{array}{l}\text { Handle a fixed user base, and in the same } \\
\text { area, high security requirements related to } \\
\text { the operating system platform }\end{array}$ \\
\hline User interface & $\begin{array}{l}\text { Built on the browser, it can communicate } \\
\text { with users in vivid forms }\end{array}$ & $\begin{array}{l}\text { Built on the window platform, the form of } \\
\text { representation is limited, and it requires } \\
\text { higher program administrators }\end{array}$ \\
\hline
\end{tabular}

\subsection{AJAX development language}

AJAX is an asynchronization of the system programming languages JavaScript and XML. It is a kind of interactive webpage development technology. Its application structure is shown in Figure 2.

XmlHttpRequest, as the JavaScript object, is the core of Ajax. This technology supports the asynchronous communication requests of web pages [9]. Therefore, when the server accepts the request and processes it accordingly, with the aid of this technology, the system will not block the users but rather provide a smooth user experience.

By using the XMLHttpRequest object which uses JavaScript and interface services to communicate with the WEB Server for data exchange, the browser page can establish asynchronous data communication between WEB Servers, thereby reducing the volume of information data requested from the server by the web page (instead of requesting the whole page) and improving the page browsing speed [10]. 


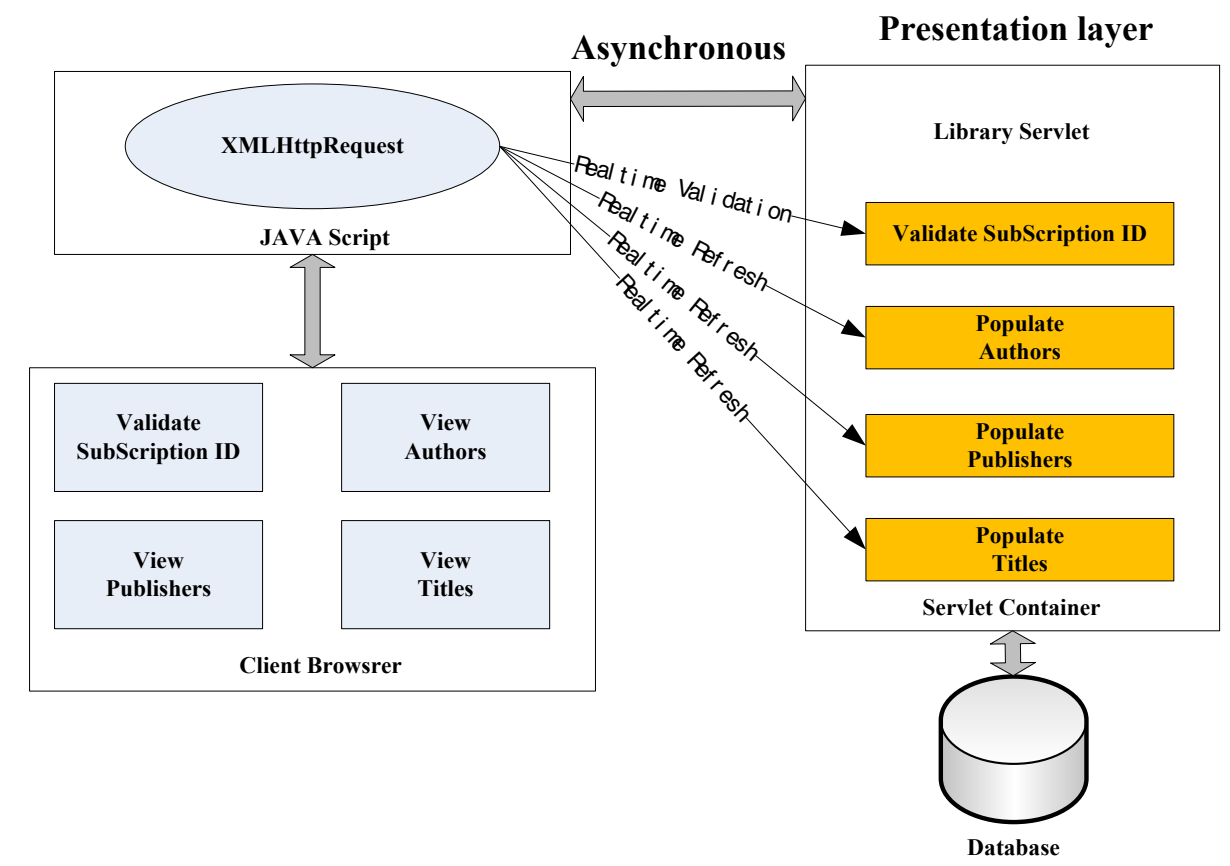

Fig. 2. AJAX application structure diagram

\subsection{MySQL}

MySQL is a popular open source SQL data management system. The MySQL service supports the use of critical service and heavy load production systems, and can also be embedded into large software [11].

The MySQL has the following features: 1. It is written in $\mathrm{C}$ and $\mathrm{C}++$ and can be tested by multiple compilers and ensures code portability; 2 . It supports operating systems like AIX, FreeBSD, Linux, Mac OS and Windows; 3. It provides APIs for multiple programming languages; 4 . It optimizes the SQL query algorithm; 5 . It improves the database query and access speed; 6 . It provides multiple database connection paths such as TCP/IP, ODBC and JDBC [12].

Although MySQL is not as large as Oracle, DB2, SQL server and other large databases, it has an objective access speed and uses open-source software code, which is less costly, making it the best choice as the database of the college accounting skills simulation practice system.

\section{$3 \quad$ Accounting skills simulation practice system}

Through research on the accounting skills teaching in colleges and universities, it is found that there are four problems at the present stage: (1) insufficient class hours for practice, making students lack the abilities to solve and analyze actual problems; (2) 
the teaching content deviates from the actual accounting needs in companies, and mostly includes voucher preparation and bookkeeping, etc., which has limited effect on training of the practical skills of students; (3) the practical training is conducted without the cooperation of companies, so students are unable to understand the current industry trends; (4) the skill assessment on students is not conducted in a reasonable way - it over-emphasizes the assessment results but neglects the tracking of the student assessment process.

In light of these problems in the current stage of accounting teaching in colleges and universities, the author analyzes the teaching needs and functional requirements for the accounting skills simulation practice system [13]. The purpose is to integrate the accounting practice simulation management with the help of computer network and computer software technologies, and gradually establish a practical accounting management system for universities and colleges by analyzing and integrating business processes, so as to provide a basic supporting platform for further improving the teaching level of practical accounting in our college [14].

\subsection{Analysis of system requirements}

The requirements for the accounting simulation practice system mainly includes: practical course management, student simulation practice learning management, practice reporting management, teaching organization and management, information query module, knowledge base module, system management and other functions. The relevant computer technologies in Section 2 are used to develop the accounting simulation practice system [15].

1. System management requirements. System management requirements can be divided into four categories: user login administration, which mainly administers user permissions and user names and passwords, etc.; practical course management, which includes adding and deleting teaching courses, adjusting course timetable, assigning and collecting homework; account management, which is based on the accounts classified according to accounting elements; accounting knowledge base management, which establishes and updates basic accounting knowledge, regulatory standards, regulations, processes, frontier academics and enterprise dynamics.

\section{Practical teaching management.}

(a) Practical teaching course management: supervising student attendance, practical learning progress and practice progress.

(b) Practice reporting and practice score management: students submit the practice reports to teachers for review, and can manage preview score, practical project score and practice report score through the system.

3. System permission management. The system needs regular maintenance and management of system user permissions. In addition, accounting training can be carried out by setting up different practical training classes, designating in-charge teachers and importing the students of the class. 


\subsection{Analysis of non-functional system requirements}

Non-functional system requirements mainly include system safety and system performance:

1. System security: ensure the correctness and legitimacy of the system's core technical software and programming language; ensure that the campus network adopts effective measures to prevent illegal intrusions and regularly investigate security breaches; and conduct system self-monitoring to avoid system paralysis.

2. System performance: system design should be simple, flexible, nice-looking and easy to use. In terms of system response, the entry of an accounting document should take less than 10 seconds; the statistics of complex query reports take less than 30 seconds; and the system should be able to accommodate 200 users under full load and 50 concurrent users.

\subsection{Operating environment of the system}

Server: windows $8 / 10$ server;

Database: My SQL;

Client: windows $8 / 10$;

Browser: 360 browser/google browser/IE browser;

Assistant software: Microsoft Office.

\section{Overall design of the accounting skills simulation practice system}

\subsection{Overall system structure design}

According to the functional requirements of the system, the overall structural design of the accounting skills simulation practice system is clear. The accounting skills simulation practice system based on the $\mathrm{B} / \mathrm{S}$ architecture is divided into four layers, namely front-end presentation layer, business application layer, application support layer, and software platform layer. 


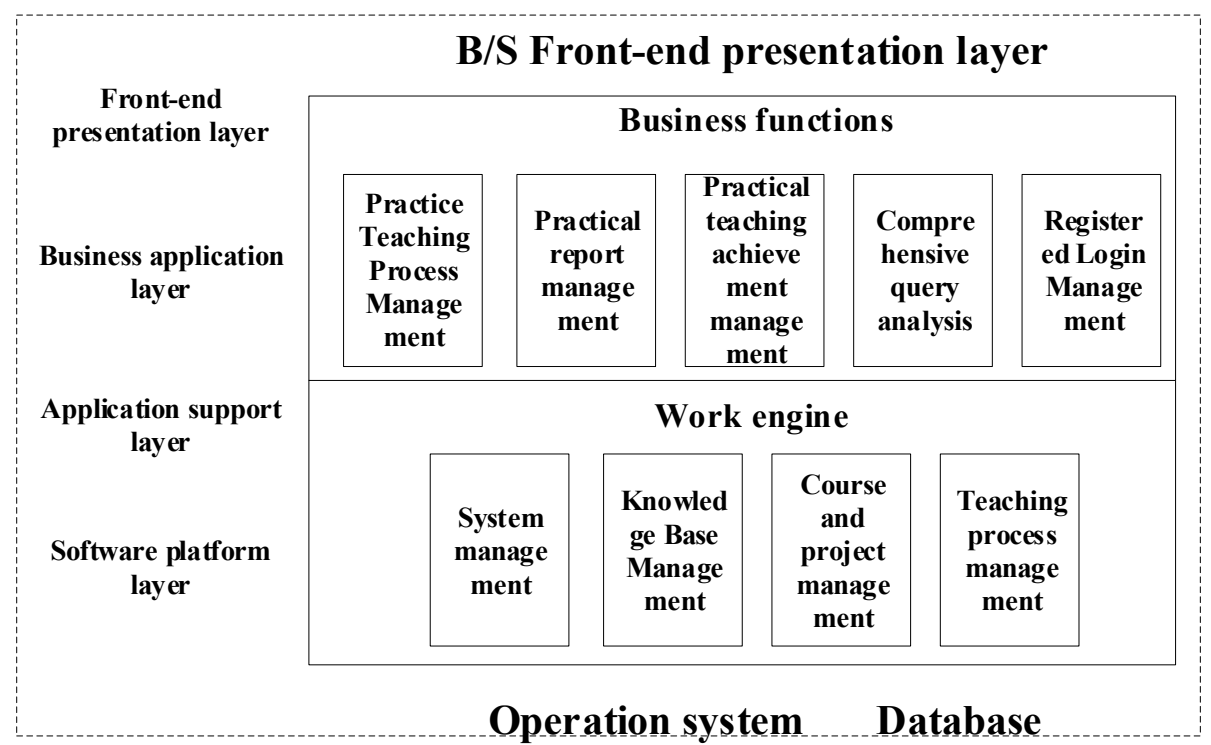

Fig. 3. System overall architecture

\subsection{User rights of the accounting simulation practice system}

System administrator. The administrator can query, add, modify, or delete the information of accounting teachers; assign classes to corresponding teachers; and modify or delete each teacher's classes. The administrator maintains personal information and maintains and administers the classes managed by the teachers by accessing the backend management module.

The system requirements for the management module include adding and deleting teachers, modifying and querying teachers' information, adding classes, deleting classes and modifying and querying class information.

Teachers. Teachers need to be able to log in the system, maintain personal information and access the teacher function module to perform appropriate operations. They need to complete the query and management of students' practice progress and accounting scores in the system and design students' comprehensive accounting ability tests and practical skills tests. After students complete relevant tests, they will inquire about students' scores in order to understand students' learning status and track students' practice reports and progress in the system.

Students. Students need to log in the system and maintain personal information. In the system, they learn the theories of accounting skills, and at the same time participate in the accounting function simulation practical training by themselves. In the process, the intervention of the teacher greatly increases the students' initiatives in learning. On the one hand, they can learn and practice freely; and on the other hand, due to the limited degree of freedom, their learning efficiency can increase. 


\subsection{Database design}

The conceptual design of database refers to the analysis and collation of acquired information and data, and the determination of the entities, attributes and their relationships, that is, designing the conceptual model of the database through the entity-relationship method. Preparations are made for the database storage by designing the fields, field types, lengths and other attributes in the database table of key parameters. Table 2 shows the database storage method of the chart of accounts.

Table 2. Chart of accounts

\begin{tabular}{|c|c|c|c|}
\hline Fields & Date names & Home key or not & Field description \\
\hline Subject_id & Int & $\mathrm{Y}$ & Automatic growth \\
\hline Parent & Int & $\mathrm{N}$ & From the upper node \\
\hline Code & Varchar(50) & $\mathrm{N}$ & Account Code \\
\hline Name & Varchar(200) & $\mathrm{N}$ & Account Name \\
\hline Mnemocode & Varchar(200) & $\mathrm{N}$ & Assist memory code \\
\hline Subject_type & Int & $\mathrm{N}$ & Account table \\
\hline Account Over_id & Int & $\mathrm{N}$ & Account set of books \\
\hline
\end{tabular}

In addition, the account type information table, account category, account set information, accounting period information, voucher type, voucher information, and other data tables can all be stored through the E-R entity structure.

\subsection{System interface design and implementation}

User login management. In order to ensure the security of the accounting simulation practice system, users must undergo permission authentication when logging in the system. After user permissions are verified, users obtain the appropriate permissions from the main program. Figure 4 shows the system user login interface.

After opening the system, the user will first select the user type. After entering the username and password, the system will verify the authenticity of the user information in the database. After logging in the system, the current user will be tagged as an online user.

Accounting skills practice reporting management interface. In the system-based accounting simulation practice teaching environment, students can complete online practice vouchers, accounts, performance inquiries and other functions. Figure 5 shows the practice score management interface.

After accessing the practical course, the student can practice the unit exercises and save the practice results at any time. After completing the relevant documents, the system will automatically calculate the practice results according to the actual performance and print the practice report.

In addition, the system also has a skill practice score management interface, a comprehensive information query interface and a system permission management interface, etc. as Due to the space limitation, they will not be displayed one by one. Through these 
functional interfaces, the accounting skills simulation system based on the $\mathrm{B} / \mathrm{S}$ architecture can well meet the system requirements and user requirements, and achieve the design expectations. In the system test, the system achieved stable results. In summary, this system has advantages like complete interfaces, simple operation and data security.

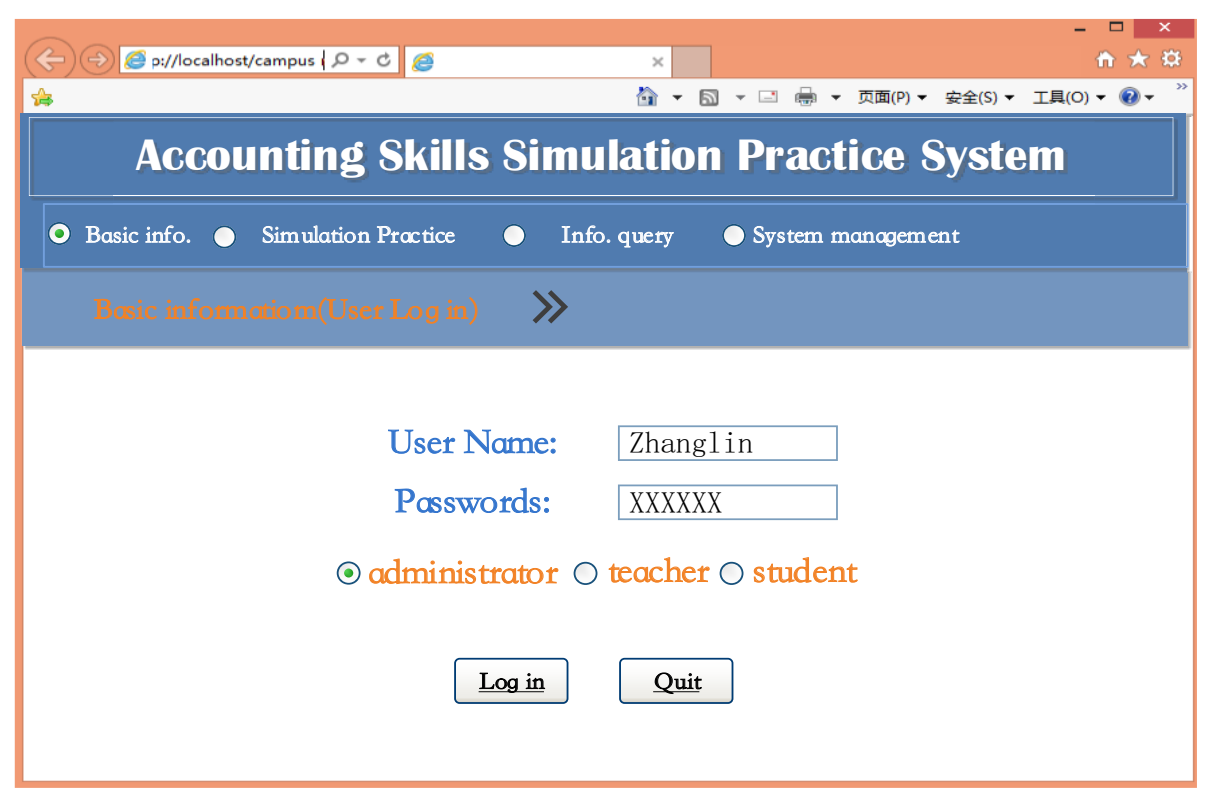

Fig. 4. Login interface of the system

\begin{tabular}{|c|c|c|}
\hline$\Leftrightarrow \Leftrightarrow \mathrm{p:}$ & //localhost/camp & pus $\{0-\mathrm{c}$ e \\
\hline$\Leftrightarrow$ & & 回 - \\
\hline Ald & BCOUnt & ting Skills Simulation Practice System \\
\hline • & & - \\
\hline Table ID & Table name & \begin{tabular}{|c|} 
Test \\
\end{tabular} \\
\hline \begin{tabular}{|l|l|}
$\mathrm{Kj} b b_{-} I \mathrm{rb}$ \\
\end{tabular} & Profit table & Puery documents and test Practical training Public Background Table Appl i cation \\
\hline$|j \mathrm{bb}-z c f z|$ & \begin{tabular}{c|c} 
Bal ance \\
sheet
\end{tabular} & puery documents and test Practical training Publ ic Background Table Applicati on \\
\hline Kj bb_xjl & Cash sheet & Euery documents and test Practical training Public Background Table Application \\
\hline Kj zd_bxdd & \begin{tabular}{c|c}
$\begin{array}{c}\text { Rei mbur se } \\
\text { ment }\end{array}$ & - \\
\end{tabular} & puery documents and test Practical training Public Background Table Application \\
\hline Kj dz_ckd & $\begin{array}{c}\text { Out bound } \\
\text { or der }\end{array}$ & puery documents and test Practical training Public Background Table Application \\
\hline $\mathrm{Kj} d z=\mathrm{ckm}$ & $\begin{array}{l}\text { Deposit } \\
\text { details }\end{array}$ & puery documents and test Practical training Publ ic Background Table Application \\
\hline Kj dz & \begin{tabular}{|l|} 
Tr avel \\
expense \\
st at ement
\end{tabular} & puery documents and test Practical training Public Background Table Application \\
\hline
\end{tabular}

Fig. 5. Practice score management interface 


\section{Conclusions}

In light of the imbalance between theoretical knowledge and practical operations currently in the accounting education in colleges and universities, this paper proposes an accounting skills simulation practice system for colleges and universities based on the $\mathrm{B} / \mathrm{S}$ architecture. Based on the introduction to the computer technology, it first performs detailed analysis of the system user requirements and system functional requirements; then it selects appropriate network architecture, programming language and database software, and completes the overall system design; at last, after the accounting skills simulation system is completed, it displays relevant interfaces. The main content and innovations of this paper are as follows:

1. With $\mathrm{B} / \mathrm{S}$ as the software architecture, MySQL as the database development tool and AJAX as the programming technology, this paper completes the design of the accounting skills simulation practice system, which meets users' functional and nonfunctional requirements.

2. By combining the computer technologies and accounting teaching characteristics, this paper designs the functional modules for accounting skills teaching. This system gives a new way for accounting teaching and learning, promotes the accounting teaching reform and provides support for the cultivation of talents with both theoretical knowledge and practical skills in colleges and universities

3. The system is safe, scalable and flexible, which facilitates the secondary development of the system to meet users' new functional requirements.

\section{References}

[1] Lin, L. (2007). A methodological framework for the triple bottom line accounting and management of industry enterprises. International Journal of Production Research, 45(5): 10631088. https://doi.org/10.1080/00207540600635136

[2] Lodhia, S., Hess, N. (2014). Sustainability accounting and reporting in the mining in-dustry: current literature and directions for future research. Journal of Cleaner Produc-tion, 84: 4350. https://doi.org/10.1016/i.jclepro.2014.08.094

[3] Kocher, B. (2002). A model for software practices from the accounting profession. IEEE Software, 17(1): 57-60. https://doi.org/10.1109/52.819969

[4] Yuniarta, G.A. (2013). Pengembangan, software of hospitality accounting dictionary. Physics Letters A, 140(6): 288-290.

[5] Rozanov, V.V., Dinter, T., Rozanov, A.V., Wolanin, A., Bracher, A., Burrows, J.P. (2017). Radiative transfer modeling through terrestrial atmosphere and ocean account-ing for inelastic processes: software package sciatran. Journal of Quantitative Spec-troscopy \& Radiative Transfer, 194: 65-85. https://doi.org/10.1016/j.jqsrt.2017.03.009

[6] Gokhale, S.S., Lyu, R.T. (2005). A simulation approach to structure-based software re-liability analysis. IEEE Transactions on Software Engineering, 31(8): 643-656. https://doi.org/10.1109/TSE.2005.86

[7] Wang, X.X., Zou, Z.R., Fan, C., He-Zhen, L.I. (2011). Design and implementation of environmental fundamental data management system based on $\mathrm{b} / \mathrm{s}$ structure. Envi-ronmental Science \& Technology, 34(2): 197-200. 
[8] Cui, A.J., Ming, L.U., Liang, Y.P. (2005). Analysis and design of hybrid c/s and b/s structure-based marine science and technology archives management system. Coastal Engineering.

[9] Serrano, N., Aroztegi, J.P. (2007). Ajax frameworks in interactive web apps. IEEE Software, 24(5): 12-14. https://doi.org/10.1109/MS.2007.132

[10] Salva, S., Laurençot, P. (2009). Automatic ajax application testing. IEEE. https://doi.org/10.1109/ICIW.2009.40

[11] Giacomo, M. D. (2005). Mysql: lessons learned on a digital library. IEEE Software, 22(3): 10-13. https://doi.org/10.1109/MS.2005.71

[12] Boyd, S.W., Keromytis, A.D. (2004). Sqlrand: preventing sql injection attacks. Lec-ture Notes in Computer Science, 3089: 292-302. https://doi.org/10.1007/978-3-540-24852-1 21

[13] Firdausy, K., Samadri, Yudhana, A. (2008). Web based library information system us-ing php and mysql. Telkomnika, 6(2).

[14] Sadideen, H., Kneebone, R. (2012). Practical skills teaching in contemporary surgical education: how can educational theory be applied to promote effective learning. American Journal of Surgery, 204(3): 396-401. https://doi.org/10.1016/j.amjsurg.2011.12.020

[15] Austin, Z., Dolovich, L., Lau, E., Tabak, D., Sellors, C., Marini, A. (2005). Teaching and assessing primary care skills: the family practice simulator model. American Journal of Pharmaceutical Education, 69(4): 60-61. https://doi.org/10.5688/aj690468

\section{$7 \quad$ Authors}

Jianmei Liu received her B.Sc. degree in 2008 from accounting in the Chongqing University of Communications and Posts. And she received her M.Sc. degree in 2011 from accounting in Southwestern University of Finance and Economics. Now she is an accounting teacher in Chongqing Three Gorges University. Her main research interests include accounting theory and practice.

Rong Fu received her B.Sc. degree in 2004 from information technology in the Chengdu University of Technology. And she received her M.Sc. degree in 2010 from a very Technical economy and management in Yunnan University. Now she is an accounting teacher in Chongqing Three Gorges University. Her main research interests include accounting theory and accounting informatization.

Article submitted 17 July 2018. Resubmitted 29 July 2018. Final acceptance 10 August 2018. Final version published as submitted by the authors. 